\title{
KAJIAN PSIKOLOGI SIGMUND FREUD DALAM NOVEL SETETES EMBUN CINTA NIYALA KARYA HABIBURRAHMAN EL SHIRAZY
}

\author{
Pipik Asteka \\ Pendidikan Bahasa dan Sastra Indonesia \\ Universitas Majalengka \\ e-mail: pipikasteka86@gmail.com
}

\begin{abstract}
ABSTRAK
Tujuan penelitian ini untuk mendeskripsikan tentang konflik batin tokoh utama berdasarkan aspek psikologi sastra yang terdapat dalam novel Setetes Embun Cinta Niyala karya Habiburrahman El Shirazy. Data penelitian ini dianalisis dengan metode penelitian deskriptif kualitatif. Objek penelitian ini adalah kajian psikologi sastra oleh Sigmund Freudian dengan meninjau aspek-aspek id, ego, dan superego. Subjek penelitian ini adalah novel Setetes Embun Cinta Niyala karya Habiburrahman El Shirazy. Hasil penelitian berbicara tentang aspek id, ego, dan superego tokoh utama Niyala dalam novel terjadi konflik batin. Konflik batin mereka terjadi mencerminkan kejadian yang terjadi. Dalam sosok Niyala terjadi keseimbangan antara aspek $i d$, ego, dan superego.pada novel tersebut dapat ditarik kesimpulan bahwa terjadi aspek $i d$, Niyala lebih memilih dirinya mati daripada harus memenuhi isi surat itu, namun nuraninya sebagai seorang anak yang shaleh dan berbakti membuat kacau pikirannya, aspek ego, tokoh Niyala adalah seorang anak yang berbakti dan shalehah. Ia tidak sanggup menolak permintaan dari ayahnya itu mengenai perjodohan yang dihadapkan padanya. Ia berusaha mencari jalan keluar dari permasalahan yang sedang ia alami saat ini tanpa ada yang harus ia korbankan dan aspek superego, Faiq berperan sebagai superego yang menjadi penyeimbang dan penyelesai konflik batin yang dialami Niyala dari dorongan aspek id dan ego yang mempengaruhinya.
\end{abstract}

Kata Kunci: id, ego, superego, tokoh utama, konflik batin.

\section{PENDAHULUAN}

Sebuah karya sastra pada hakikatnya merupakan suatu pengungkapan kehidupan melalui bentuk bahasa. Karya sastra merupakan pengungkapan baku dari apa yang telah disaksikan, diilhami, dan dirasakan seseorang mengenai segi-segi kehidupan yang menarik minat secara langsung dan kuat, pada hakikatnya suatu pengungkapan kehidupan manusia melalui bentuk bahasa (Hardjana,1981:10).

$$
\text { Karya sastra berusaha }
$$

menggambarkan kehidupan manusia, tidak hanya dalam hubungan dengan manusia lain, tetapi juga hubungannya dengan dirinya sendiri melalui hubungan peristiwa batin.
Salah satu bentuk karya sastra adalah novel. Nurgiyantoro (1995:11) mengemukakan bahwa novel dapat menggambarkan sesuatu secara bebas, menyatakan sesuatu yang lebih banyak, lebih rinci, lebih detail, dan lebih banyak melibatkan berbagai permasalahan yang lebih kompleks. Menurut Muhardi dan Hasanuddin (1992:6) mengemukakan bahwa novel adalah sebuah cerita yang memuat beberapa kesatuan persoalan disertai dengan faktor penyebab dan akibatnya. Persoalan kehidupan yang diangkat seperti kesedihan, kegembiraan, pengkhianatan, kejujuran, dan permasalahan kehidupan lainnya.

Menurut Semi (1988:35), novel sebagai salah satu karya sastra secara garis 
besar dibagi atas dua bagian (1) struktur luar (ekstrinsik) dan (2) struktur dalam (intrinsik). Struktur luar atau ekstrinsik adalah segala macam unsur yang berada di luar suatu karya sastra yang ikut mempengaruhi kehadiran karya sastra tersebut, misalnya faktor sosial ekonomi, faktor kebudayaan, faktor sosio-politik, keagamaan, dan tata nilai yang dianut masyarakat. Struktur dalam atau intrinsik adalah unsur-unsur yang membentuk karya sastra, terdiri atas: (1) penokohan atau perwatakan, yaitu menyangkut siapa tokoh dan bagaimana perwatakan tokoh dalam cerita; (2) tema, merupakan pokok pembicaraan yang ingin disampaikan oleh pengarang; (3) alur (plot), merupakan rentetan peristiwa yang merupakan rangkaian pola, tindak tanduk tokoh dalam memecahkan konflik yang terdapat dalam novel;(4) latar, merupakan lingkungan atau tempat peristiwa itu diamati, termasuk di dalamnya waktu, hari, tahun, musim, dan periode sejarah; (5) gaya penceritaan, yaitu tingkah gaya bahasa pengarang dalam menyampaikan cerita; (6) pusat pengisahan, yaitu posisi atau penempatan pengarang dalam bercerita, apakah pengarang sebagai tokoh utama dalam cerita, tokoh sampingan, sebagai orang ketiga (pengamat) atau sebagai pemain (narator).

Dalam meneliti sebuah karya sastra, langkah utama yang cukup penting adalah memilih pendekatan terlebih dahulu. Abrams (dalam Muhardi dan Hasanuddin, 199: 4344) menyimpulkan empat karakteristik pendekatan analisis sastra, yakni, (1) pendekatan objektif merupakan suatu pendekatan yang hanya menyelidiki karya sastra itu tahap menghubungkan dengan halhal yang di luar karya sastra, (2) pendekatan mimesis merupakan pendekatan yang setelah menyelidiki karya sastra sebagai suatu otonom, masih merasa perlu menghubungkan hasil temuan itu dengan realita objektif. (3) pendekatan ekspresif merupakan pendekatan yang setelah karya sastra sebagai suatu otonom, masih merasa perlu mencari hubungannya dengan pengarang sebagai penciptanya, dan (4) pendekatan pragmatis merupakan pendekatan yang memandang penting menghubungkan temuan dalam sastra itu dengan pembaca sebagai penikmat.

Berdasarkan uraian di atas, maka dalam hal ini penulis akan mengkaji tentang konflik batin tokoh utama. Novel yang dipilih dalam penelitian ini adalah novel Setetes Embun Cinta Niyala karya Habiburrahman El Shirazy terdapat banyak konflik batin di dalammya dan layak untuk dikaji. pengarang lebih memusatkan pikiran pembaca pada permasalahan keluarga. Setetes Embun cinta Niyala bertemakan cinta yang tak terduga sebagai inti pemasalahanya. Bercerita tentang seorang akhwat lulusan fakultas kedokteran di salah satu universitas negeri di Jakarta. Akhwat tersebut adalah seorang gadis solehah bernama Niyala. Kenyataan akan masa depannya tak sesuai dengan apa yang ia bayangkan.

Berdasarkan latar belakang masalah mengenai kajian psikologi sastra dalam novel Setetes Embun Cinta Niyala, maka dapat dirumuskan permasalahannya, yaitu Bagaimana konflik batin tokoh utama berdasarkan aspek psikologi sastra yang terdapat dalam novel Setetes Embun Cinta Niyala karya Habiburrahman El Shirazy.

\section{KAJIAN TEORI Teori Psikologi Sigmund Freud}

Teori ini menganalisis kehidupan jiwa manusia sampai pada alam bawah sadar, karena sebagai makhluk individu, seorang manusia selalu mengalami konflik batin dalam keresahan dan ketekanan jiwa.

Psikologi merupakan ilmu yang mempelajari perilaku dan aspek kejiwaan manusia. Terdapat beberapa kajian psikologi dan yang berkaitan dengan penelitian adalah psikologi kepribadian. Hal itu mengingat bahwa penelitian ini menganalisis tentang tingkah laku manusia (tokoh) guna memperoleh tipologi kepribadian tertentu berdasarkan karakter tokoh tersebut.

Teori psikologi Sigmund Freud (dalam Albertine Minderop, 2010: 10-11) 
membandingkan jiwa manusia dengan gunung es yaitu bagian yang lebih kecil yang timbul di permukaan air menggambarkan daerah ketidaksadaran. Sigmund Freud (dalam Albertine Minderop, 2010: 20-21) membagi susunan kepribadian manusia menjadi tiga system, yaitu:

1. Das $\boldsymbol{E}$ s atau Id, merupakan aspek biologis dan sebagai lapisan kejiwaan yang paling dasar. Id berisiskan hal-hal yang dibawa sejak lahir, yaitu naluri-naluri bawaan (seksual dan agresif), termasuk keinginan-keinginan yang direpresi. Id berfungsi untuk mencapai kepuasan bagi keinginan nalurinya sesuai prinsip kesenangan. Oleh karenanya $I d$ tidak mengenal hukum akal dan Id tidak memiliki nilai estetika atau akhlak. Hanya ada dua kemungkinan bagi proses $I d$, yaitu berusaha memuaskan keinginan atau menyerahkan kepada pengaruh $e g o$.

2. Das Ich atau Ego, merupakan aspek psikologi dari kepribadian yang timbul karena kebutuhan untuk berhubungan dengan dunia kenyataan (realita). Ego mempergunakan energi psikis yang dikuasai untuk mengintegrasikan ketiga aspek kepribadian, agar timbul keselarasan batin sehingga hubungan antara pribadi dengan dunia luar dapat mempergunakan energi psikis secara baik maka akan timbul konflik internal atau konflik batin yang diekspresikan dalam bentuk tingkah laku yang pathlogis dan abnormal.

3. Das Ueber Ich atau The Superego, merupakan aspek psikologi kepribadian yang fungsi pokoknya menentukan benar salahnya atau susila tidaknya sesuatu. Dengan demikian, pribadi dapat bertindak sesuai dengan moral masyarakat. Yang merupakan system kepribadian yang berisikan nilai-nilai dan aturan-aturan yang sifatnya evaluative (menyangkut baik-buruk) yang diajarkan dengan perintah dan larangan yang dilakukan dengan norma-norma agama. Superego cenderung menentang baik Id maupun Ego, dan membuat dunia menurut konsepsi yang ideal.

\section{METODOLOGI PENELITIAN}

Metode yang digunakan dalam penelitian ini adalah metode kualitatif deskriptif dengan menggunakan data dari novel Setetes Embun Cinta Niyala Karya Habibburahman El-Shirazy yang diterbitkan oleh Republika penerbit pada tahun 2005 setebal 58 halaman. Teknik pengumpulan data pada novel dengan teknik baca dan catat. Teknik ini digunakan untuk mendeskripsikan tokoh utam dalam novel dilakukan dengan cara mendeskripsikan teksteks yang menyangkut tokoh dalam novel. Adapun Prosedur analisis data pada penelitian adalah sebagai berikut.

1. Membaca teks sastra (dalam hal ini adalah novel Setetes Embun Cinta Niyala Karya Habibburahman ElShirazy).

2. Menentukan ujaran yang mengandung karakter tokoh secara tersurat maupun tersirat.

3. Mencari, menentukan, dan menganalisis karakter tokoh yang ada dalam novel, berdasarkan teknik psikoanalisis Sigmund Freud.

4. Menyimpulkan karakter tokoh berdasarkan temuan pada point 3

\section{HASIL DAN PEMBAHASAN}

Tokoh Aku dan Niyala adalah dua tokoh utama pada novel Setetes Embun Cinta Niyala Karya Habibburahman El-Shirazy. Posisi tokoh utama itu ditetapkan berdasarkan penelusuran terhadap tokohtokoh yang ada dalam novel Setetes Embun Cinta Niyala Karya Habibburahman ElShirazy. Tokoh Aku merupakan tokoh yang banyak diceritakan dalam novel tersebut. Tokoh Aku sering terlibat dengan tokoh lain, baik secara langsung maupun tidak langsung. Selain itu, tokoh yang selalu muncul dalam cerita dan mengalami berbagai konflik batin adalah Tokoh utama dan Niyala.

Dalam pembahasan ini dapat dianalisis berdasarkan data yang dilakukan terhadap novel Setetes Embun Cinta Niyala Karya Habibburahman El-Shirazy dengan menggunakan kajian psikologi sastra dengan 
mencari peran serta perwatakannya dapat membantu menemukan konflik batin yang terjadi pada tokoh utama dan dianalisis dengan menggunakan teori Psikologi Sigmund Freud yaitu aspek id, ego, dan superego.

\section{1. $\quad$ Aspek Id $\rightarrow$ Tokoh Niyala}

Aspek id tokoh Niyala muncul pada saat ia menerima surat yang dikirim ayahnya dari Sidempuan perihal perjodohan dirinya dengan Roger. Niyala tidak menginginkan perjodohan itu. Dorongan aspek id dari dalam dirinya membuat ia kebingungan untuk berhadapan dengan masalah tersebut. Berikut kutipannya.

(1)"Oh, haruskah aku gadaikan hidupku ini? Pasrah tercampak tanpa mimpi mulia seperti pelacur hina yang kalah oleh nafsunya. Hampa, pahit dan getir tanpa cinta. Oh! Bukankah lebih baik aku mati saja jika aku menyerahkan mahkota kehormatan tanpa cinta. Menerima pasangan hidup dengan hati perih tersiksa. Merentas hidup baru hanya untuk mereguk nestapa selamanya. Melayani suami tanpa cinta. Terpaksa dan tersiksa. Melahirkan anak tanpa rasa bangga. Hidup selamanya di atas derita batin tiada tara." (Shirazy, 2005:49)

Dapat disimpulkan bahwa, Niyala lebih memilih dirinya mati daripada harus memenuhi isi surat itu, namun nuraninya sebagai seorang anak yang shaleh dan berbakti membuat kacau pikirannya.

\section{2. $\quad$ Aspek Ego $\rightarrow$ Tokoh Niyala}

Pada tokoh Niyala aspek ego dipertahankan untuk mencapai kepuasan dan terpenuhi aspek idnya. Niyala berusaha mencari jalan terbaik agar ia tidak menjadi istri Roger dan tidak mengorbankan ayahnya untuk permasalahan hutang piutang yang sedang dialaminya. Berikut kutipannya.

(4)"'Ia masih berpikir keras berhari-hari. Mencari-cari jalan keluar terbaik yang melepaskan dirinya dan ayahnya dari keadaan yang menyesakkan dada itu. Namun tidak juga ia temukan. Ia harus berkorban, atau ayahnya yang harus ia korbankan dengan cara menolak mentah-mentah permintaan itu. Namun nurani terdalam sebagai seorang anak yang mencintai ayahnya tidak sampai melakukan itu.

“....andai ia punya delapan puluh juta tentu semuanya akan mudah baginya. Tapi dari mana ia bisa mendapatkan uang sebanyak itu." (Shiarazy, 2005:59)

Dapat disimpulkan bahwa tokoh Niyala adalah seorang anak yang berbakti dan shalehah. Ia tidak sanggup menolak permintaan dari ayahnya itu mengenai perjodohan yang dihadapkan padanya. Ia berusaha mencari jalan keluar dari permasalahan yang sedang ia alami saat ini tanpa ada yang harus ia korbankan.

\section{Aspek Superego $\rightarrow$ Tokoh Niyala}

Aspek superego pada diri Niyala muncul pada saat Faiq kakak angkatnya itu menyatakan keseriusan dirinya yang ingin menikahi Niyala. Berikut kutipannya.

"Kenapa tiba-tiba kau ragu adikku? Apa kau masih menyasingkan kebulatan niat kakak untuk membahagiakanmu?"

Mata Niyala berkaca-kaca, "Apakah ini sungguhan ataukah Cuma sandiwara? Ataukah hanya mimpi?" tanyanya dengan terisak. "Ini sungguh dan serius. Kita akan menikah secepatnya. Dan kita akan tetap tinggal bersama di rumah mungil ini dengan penuh cinta. Kita akan mereda masa depan bersama. Dan akan membesarkan anak-anak kita nanti bersama. Apakah kau tidak mau mewujudkan impian ini?" (Shirazy, 2005:95)

Dapat disimpulkan, Faiq berperan sebagai superego yang menjadi penyeimbang dan penyelesai konflik batin yang dialami Niyala dari dorongan aspek id dan ego yang mempengaruhinya.

\section{SIMPULAN}

Berdasarkan analisis dalam bab-bab sebelumnya, penelitian ini diakhiri dengan simpulan sebagai berikut. Konflik batin tokoh utama dalam novel Setetes Embun Cinta Niyala Karya Habibburahman ElShirazy, pada novel tersebut dapat ditarik 
kesimpulan bahwa terjadi keseimbangan antara aspek id, ego, dan superego yang dialami Niyala. Pendorong id disaring dan dipuaskan dengan ego. Ego menyaring dorongan yang ingin dipuaskan oleh aspek id. Aspek id Niyala menonjol sejak kedatangan surat yang dikirim ayahnya dari Sidempuan. Superego menjadi pengendali dan penyelesai dari permasalahan yang muncul.Data dari penelitian ini dapat disimpulkan bahwa cerita tentang novel Setetes Embun Cinta Niyala karya Habiburrahman El Shirazysebagai berikut.

1. Dapat disimpulkan bahwaaspek $i d$, Niyala lebih memilih dirinya mati daripada harus memenuhi isi surat itu, namun nuraninya sebagai seorang anak yang shaleh dan berbakti membuat kacau pikirannya.

2. Dapat disimpulkan bahwa aspek ego, tokoh Niyala adalah seorang anak yang berbakti dan shalehah. Ia tidak sanggup menolak permintaan dari ayahnya itu mengenai perjodohan yang dihadapkan padanya. Ia berusaha mencari jalan keluar dari permasalahan yang sedang ia alami saat ini tanpa ada yang harus ia korbankan.
3. Dapat disimpulkan bahwa aspek superego, Faiq berperan sebagai superego yang menjadi penyeimbang dan penyelesai konflik batin yang dialami Niyala dari dorongan aspek id dan ego yang mempengaruhinya.

\section{DAFTAR PUSTAKA}

Moleong, Lexy J. 2004. Metodologi Penelitian Kualitatif Edisi Revisi. Bandung: PT Remaja Rosdakarya.

Nurgiyantoro, Burhan. 1995. Teori Pengakajian Fiksi. Yogyakarta: Gajah Mada University Press.

Minderop, Albertine. 2010.Psikologi Sastra. Jakarta: Yayasan Pustaka Obor Indonesia.

Shirazy, Habiburrahman El. 2005. Pudarnya Pesona Cleopatra. Jakarta: Republika.

Sujanto, Agus, dkk. 2009. Psikologi Kepribadian. Jakarta: Bumi Aksara. 